\title{
TVOCs EMISSIONS FROM DISINFECTANTS, BONDING AGENTS AND ACRYLIC SUBSTANCES IN A CONTROLLED DENTAL OFFICE
}

\author{
HALIOS C.H. ${ }^{1, *}$ \\ HELMIS C.G. ${ }^{2}$ \\ SGOUROS G. ${ }^{2}$ \\ TZOUTZAS $\mathrm{J}^{3}$ \\ ANTONIADOU $\mathrm{M}^{3}$ \\ KOSTOPOULOS V. ${ }^{2}$
}

\author{
${ }^{1}$ Department of Meteorology, University of Reading, UK \\ ${ }^{2}$ National and Kapodistrian University of Athens, \\ Faculty of Physics, Department of Environmental Physics and \\ Meteorology, Building PHYS-5, University campus, \\ 15784, Athens, Greece \\ ${ }^{3}$ Department of Operative Dentistry, Dental School, \\ University of Athens, Greece
}

Received: $12 / 04 / 13$

Accepted: 22/05/13 *to whom all correspondence should be addressed: e-mail: c.halios@reading.ac.uk

\begin{abstract}
The aim of this study, which took place in a dental environment located at the centre of Athens, Greece, is to quantify the amount of Total Volatile Compounds (TVOCs), which were emitted from commonly used dental substances in a controlled dental micro-environment (8 surface disinfectants including both sprays and tissues, 8 bonding agents and 4 acrylic substances). TVOCs concentrations were monitored at three distances from the source (right above the source, $50 \mathrm{~cm}$ and $100 \mathrm{~cm}$ distance from the source) for a period of minutes using a ppbRAE monitor. The environmental factors were complementary assessed using a prototype experimental setup consisted of a sonic anemometer and a hygrometer right above the source. Ventilation rates were estimated via $\mathrm{CO}_{2}$ concentrations.

High TVOCs concentrations were found to be emitted from three out of the four acrylic substances, with average values as high as $42.000 \mathrm{ppb}$. Concentrations were substantially reduced away from the source (average values below $500 \mathrm{ppb}$ for all substances). For disinfectants, above the source the concentrations ranged between $30.430 \mathrm{ppb}$ and $10 \mathrm{ppb}$ with an average value of $5.393 \mathrm{ppb}$. Significant differences were observed between TVOCs emitted from sprays which in general, were substantially higher than TVOCs emitted from wipes (average TVOCs conc. from sprays $8.327 \mathrm{ppb}$, while the respective value for tissues is $496 \mathrm{ppb}$ ).

An effort was made to assess the dependence of the measured TVOCs concentrations on environmental factors such as wind speed and ventilation rates. It was found that the influence of environmental factors is not traceable, indicating the importance of emission patterns.
\end{abstract}

KEYWORDS: Dentistry, dental materials, Total Volatile Compounds, Indoor air quality.

\section{INTRODUCTION}

During the last decades air quality has become one of the major environmental concerns in an international level due to the possible adverse health effects to public health. Risks to human health include respiratory disorders such as asthma (Evans et al., 2008), building-related illness (Pappas et al., 2000) and cancer (Wolkoff et al., 1998). In this context, air quality studies in indoor workplace microenvironments such as clinics and dental settings have been conducted (Godwin et al., 2003; Helmis et al., 2007). Especially in the case of dental settings, substances such as acrylate compounds, organic solvents, disinfectants and polymeric dental materials routinely used in most dental procedures such as bonding agents, can spread into air within the dental working environment and affect the air quality possibly giving rise to dermatological and respiratory effects (Pechter et al., 2005; Marquardt et al., 2009). From these studies it was evident that the dental setting is a complex environment in which different procedures took place and different materials were used simultaneously making difficult the measurement of concentration levels of specific VOCs. Additionally, when studies are performed in big dental clinics, the various conditions involved 
in air quality measurements such as environmental factors and emission patterns can not fully be sketched, thus not allowing a reliable assessment of VOCs concentration variations.

Ideally, a dental material that is to be used in the oral cavity should be harmless to all (both soft and hard) oral tissues such as gingiva, mucosa, teeth, pulp, and bone, and it should not contain toxic, leachable, or diffusible substance that can be absorbed into the circulatory system, causing systemic toxic responses. The material also should be free of agents that could elicit sensitization or an allergic response in a sensitized patient. At the same time, materials used in common dental practice outside the oral cavity, should also be tested for possible toxicity, since patients and dental personnel can be in contact with them through respiration, for sometimes prolonged periods of time.

The aim of the present study is to apply a methodology to estimate the amount of Total Volatile Compounds (TVOCs) emitted from commonly used dental substances (disinfectants, bonding agents and acrylic substances) in a controlled dental micro-environment. Further, environmental parameters are evaluated in order to avoid negative interactions in the measurement procedure.

\section{SITE DESCRIPTION, DATA AND METHODS \\ Experimental setting and instrumentation}

The experiment took place in a dental setting $\left(13.5 \mathrm{~m}^{2}\right)$ which is part of a $98 \mathrm{~m}^{2}$ apartment, located at a densely populated area of the centre of Athens. Within the apartment, another neighbouring room was operated as a separate dental office.

Experiments took place during February and March 2010. Instrumentation included portable instruments for TVOCs and $\mathrm{CO}_{2}$ measurements, a fast sonic anemometer (CSAT Campbell) and a fast hygrometer for water vapour and $\mathrm{CO} 2$ measurements (LI-COR, LI-COR LI-7500). The anemometer and hygrometer were placed on a small home-made meteorological mast for indoor measurements at a height of $160 \mathrm{~cm}$ (Figure 1).

The portable instrumentation consisted of two indoor air quality monitors (IAQRAE and ppbRAE of RAE systems with resolution: $10 \mathrm{ppb}$ and $1 \mathrm{ppb}$ respectively, accuracy: 10\%, LDL: $20 \mathrm{ppb}$ ). ppbRAE was used for TVOCs measurements. IAQRAE measured TVOCs and $\mathrm{CO}_{2}$ concentrations, temperature and relative humidity. The ppbRAE TVOCs concentrations were data-logged every second, and 10-second mean values were further processed. IAQRAE measurements were datalogged every minute. The experimental set-up is presented in Figure 1.

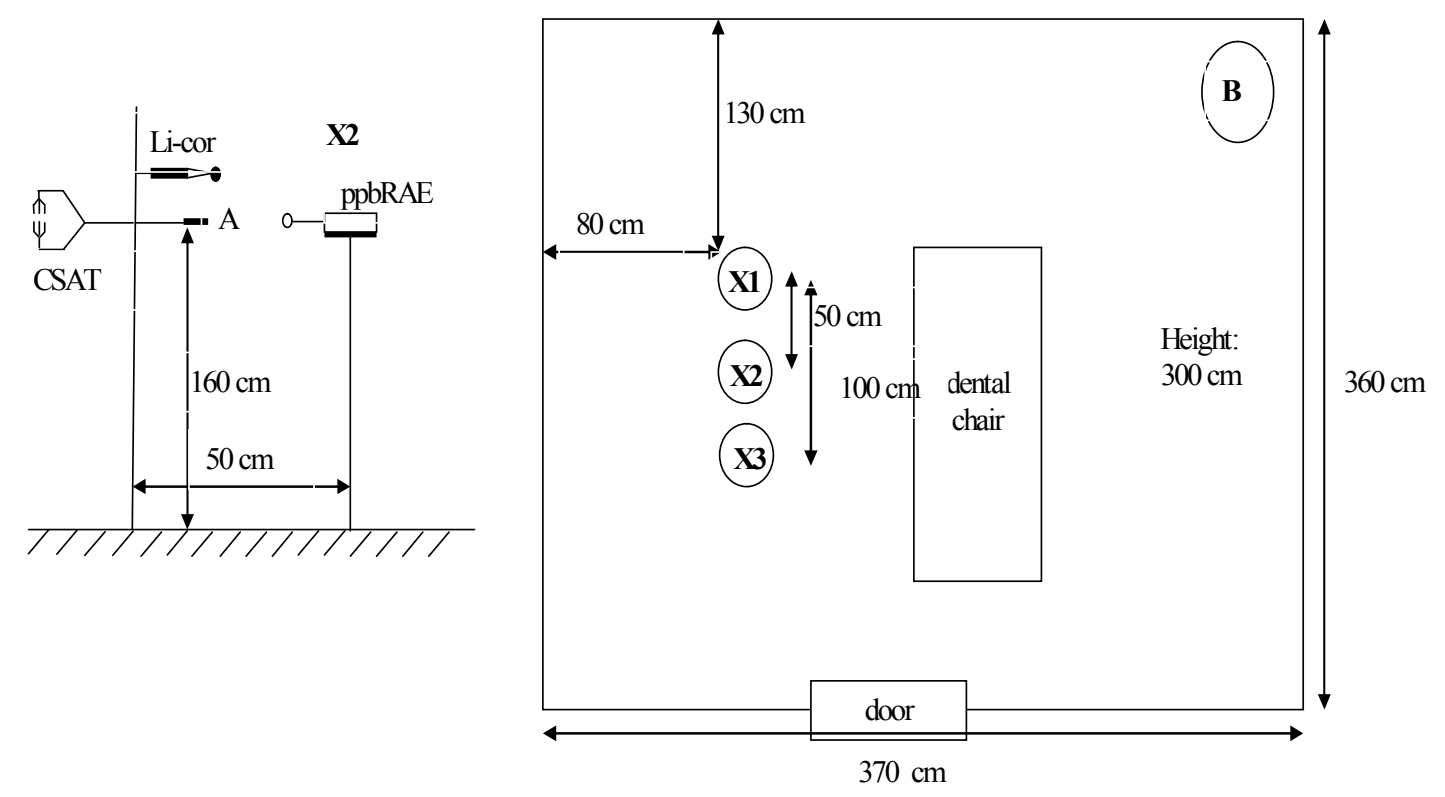

Figure 1. Dental setting and experimental set-up

\section{MATERIALS AND METHODS}

The materials used in the present study are presented in Table 1. Four categories of dental materials were examined: disinfectant sprays (SD.s, DM.s, BL.s, D.s, S.s) and wipes (BL.w, S.w, HT.w), bonding agents (Scotchbond SE (ESPE/3M), One step plus (Bisco), Optibond Solo and 
Optibond All-in -One (Kerr) AdheSE (Vivadent),Prime and Bond NT (Dentsply/DeTrey), XenoV (Dentsply/Detrey) and XP Bond ( Dentsply/Detrey) and acrylic substances (Flexacryl, Ferit, Jet, Pattern Resin). These are common substances used in dental settings.

Experimental protocol consisted of one cycle of measurements for each disinfectant. Each cycle consisted of three stages, each stage involving measurements at a certain distance from the source (substance). Three distances were chosen: $0 \mathrm{~cm}$ (right above the source $-\mathrm{X} 1$ in Figure 1), $50 \mathrm{~cm}$ and $100 \mathrm{~cm}$ away from the source (X2 and X3 in Figure 1 respectively). During each stage: (i) background TVOCs concentration were monitored and then, (ii) a certain amount of the substance was sprayed spread or deposited on the surface A (Figure 1) and the TVOCs concentrations were measured for $5 \mathrm{~min}$. In particular, $2 \mathrm{ml}$ of disinfectant sprays were sprayed, 1 drop of bonding agents was spread and five drops of acrylic substances were placed on a small disk $(2 \mathrm{~cm}$ diameter). Average background concentrations were subtracted from the measured concentrations during step (ii) at each stage and then these "clear" data was further processed for the analysis presented at the following paragraphs. This subtraction was necessary in order to exclude TVOCs produced from dental operations in the neighbouring dental office. During each cycle (i.e. TVOCs measurements resulting from different disinfectant and background values) all doors were closed. Between each cycle the door that connects the dental setting with the outdoor environment was open for 5 minutes, in order to properly dilute indoor TVOCs that were produced from the disinfectants use. Outdoor TVOCs and $\mathrm{CO}_{2}$ concentrations were monitored for 5 minutes at the beginning of the experiments during each experimental day. Wind speed and water vapour content right above the source (i.e. the spot were the dental material was sprayed or spread-A in Figure 1) were continuously measured.

The ventilation rates were calculated with the methodology followed by Helmis et al (2007), which involves the solution of the mass-balance equation for the $\mathrm{CO} 2$ concentrations, considering indoor homogeneity and negligible deposition, assumptions which are met for this particular small dental office.

Table 1. Composition of materials used in the study

\begin{tabular}{|c|c|c|c|}
\hline Material & Mode & Code & Composition \\
\hline $\begin{array}{l}\text { Bacillol AF(Bode } \\
\text { GmbH) }\end{array}$ & $\begin{array}{l}\text { Dissinf. } \\
\text { Spray }\end{array}$ & BL.s & $\begin{array}{l}\text { Propan-1-ol } 450 \mathrm{mg} \mathrm{g}^{-1} \text {, Propan-2-ol 250mg/g, } \\
\text { Ethanol } 47 \mathrm{mg} \mathrm{g}^{-1}\end{array}$ \\
\hline $\begin{array}{l}\text { Sprühdesinfektion } \\
\text { Unigloves }\end{array}$ & $\begin{array}{l}\text { Dissinf. } \\
\text { Spray }\end{array}$ & SD.s & $\begin{array}{l}\text { Ethanol 33,66/100g, 2-Propanol } 15,84 \mathrm{~g}, \\
\text { Didecyldimethylammoniumclilorid } 70 \% 0.05 \mathrm{~g} \text {, } \\
\text { pH-regulator geruchsstoffe }\end{array}$ \\
\hline $\begin{array}{l}\text { Solo Sultan } \\
\text { Healthcare Inc }\end{array}$ & $\begin{array}{l}\text { Dissinf. } \\
\text { Spray }\end{array}$ & S.s & $\begin{array}{l}\text { Alkyl phenol } 8 \text { mole, ethoxylate }(0,5 \%), \text { Alkyl } \\
\text { dimethyl benzyl ammonium chloride }(0,5 \%) \text {, } \\
\text { Didecyldimethylbenzyl ammonium chloride }(0,5 \%) \\
\text { poly(hexamethylenebiguanide) hydrochloride }(0,5 \%)\end{array}$ \\
\hline $\begin{array}{l}\text { Dentiro Mikro } \\
\text { (OCC,Switzerland) }\end{array}$ & $\begin{array}{l}\text { Dissinf. } \\
\text { Spray }\end{array}$ & DM.s & $\begin{array}{l}\text { Ethanol } 20 / 100 \mathrm{~g}, 1-P r o p a n o l \\
\text { ammonium compounds } 0.056 / 100 \mathrm{~g}\end{array}$ \\
\hline $\begin{array}{l}\text { Dürr FD } 322 \text { (Dürr } \\
\text { Dental ) }\end{array}$ & $\begin{array}{l}\text { Dissinf. } \\
\text { Spray }\end{array}$ & D.s & $\begin{array}{l}\text { 1-Propanol } 32 / 100 \mathrm{~g} \text {, Ethanol } 26 / 100 \mathrm{~g} \text {, Secondary } \\
\text { compounds, Water }\end{array}$ \\
\hline $\begin{array}{l}\text { Bacillol Tissues } \\
\text { Bode } \mathrm{GmbH} \text { ) }\end{array}$ & $\begin{array}{l}\text { Dissinf. } \\
\text { Tissue }\end{array}$ & BL.w & $\begin{array}{l}\text { 1-Propanol } 450 \mathrm{mg} \mathrm{g}^{-1}, 2 \text {-Propanol } 250 \mathrm{mg} \mathrm{g}^{-1} \text {, } \\
\text { ethanol } 47 \mathrm{mg} \mathrm{g}^{-1}\end{array}$ \\
\hline $\begin{array}{l}\text { Solo Disinfectants } \\
\text { Wipes Sultan } \\
\text { Healthcare Inc. }\end{array}$ & $\begin{array}{l}\text { Dissinf. } \\
\text { Tissue }\end{array}$ & S.w & $\begin{array}{l}\text { Alkyl phenol } 8 \text { mole, ethoxylate }(0,5 \%), \text { Alkyl } \\
\text { dimethyl benzyl ammonium chloride }(0,5 \%) \text {, } \\
\text { Didecyldimethylbenzyl ammonium chloride }(0,5 \%) \\
\text { poly(hexamethylenebiguanide) hydrochloride }(0,5 \%)\end{array}$ \\
\hline $\begin{array}{l}\text { Hygiene-Tücher } \\
\text { (Unigloves) }\end{array}$ & $\begin{array}{l}\text { Dissinf. } \\
\text { Tissue }\end{array}$ & HT.w & $\begin{array}{l}\text { 2-Propanol } 15,84 \mathrm{~g} \text {, Ethanol } 33,66 \mathrm{~g} \text {, } \\
\text { Didecyldimethylammoniumclilorid } 0.05 \mathrm{~g}\end{array}$ \\
\hline
\end{tabular}


Table 1 (continued). Composition of materials used in the study

\begin{tabular}{|c|c|c|c|}
\hline Material & Mode & Code & Composition \\
\hline $\begin{array}{l}\text { Adper Scotchbond } \\
\text { SE (3M ESPE) }\end{array}$ & $\begin{array}{l}\text { Bond. } \\
\text { Agent }\end{array}$ & $\begin{array}{l}3 \mathrm{M} \\
\mathrm{ESPE}\end{array}$ & $\begin{array}{l}\text { Component 1: HEMA, polyalkenoic acid polymer, } \\
\text { water, pink colorant Component 2: Bis-GMA, } \\
\text { UDMA, TEGDMA, TMPTMA, HEMA phosphates, } \\
\text { MHP, bonded Zirconia nanofiller, camphorquinone }\end{array}$ \\
\hline $\begin{array}{l}\text { One Step Plus } \\
\text { (Bisco) }\end{array}$ & $\begin{array}{l}\text { Bond. } \\
\text { Agent }\end{array}$ & $\begin{array}{l}\text { ONE } \\
\text { STEP }\end{array}$ & $\begin{array}{l}\text { BPDM, Bis-GMA, HEMA, acetone, photo-initiator, } \\
8.5 w \mathrm{w} \% \text { fluoroaluminosilicate glass fillers (proprietary } \\
\text { fillers) }(1 \mathrm{~mm})\end{array}$ \\
\hline $\begin{array}{l}\text { Optibond Solo Plus } \\
\text { (Kerr) }\end{array}$ & $\begin{array}{l}\text { Bond. } \\
\text { Agent }\end{array}$ & OPT & $\begin{array}{l}\text { Adhesive: Bis-GMA, HEMA, GDMA, GPDM, } \\
\text { ethanol, } \mathrm{CQ}, \mathrm{ODMAB}, \mathrm{BHT} \text {, filler (fumed } \mathrm{SiO}_{2} \text {, } \\
\text { barium aluminoborosilicate, } \mathrm{Na}_{2} \mathrm{SiF}_{6} \text { ), coupling } \\
\text { factor A174 (approximately } 15 \mathrm{wt} \% \text { filled), Ethyl } \\
\text { alcohol } 20-25 \% \text {, Alkyl dimethacrylate resins } 55- \\
60 \% \text {, Barium aluminoborosilicate glass } 5-10 \% \text {, } \\
\text { Fumed Silica (Silicon dioxide) } 5-10 \% \text {, Sodium } \\
\text { hexafluorosilicate } 0.5-1 \%\end{array}$ \\
\hline $\begin{array}{l}\text { Optibond All in One } \\
\text { (Kerr) }\end{array}$ & $\begin{array}{l}\text { Bond. } \\
\text { Agent }\end{array}$ & $\begin{array}{l}\text { OPT } \\
\text { (aio) }\end{array}$ & $\begin{array}{l}\text { Glycerol phosphate dimethacrylate (GPDM) } \\
\text { Mono- and di-functional methacrylate monomers } \\
\text { Solvents: water, acetone, ethanol } \\
\text { Camphoroquinone, fillers sodium hexafluorosilicate }\end{array}$ \\
\hline $\begin{array}{l}\text { AdheSE } \\
\text { (Vivadent) }\end{array}$ & $\begin{array}{l}\text { Bond. } \\
\text { Agent }\end{array}$ & $\mathrm{ADH}$ & $\begin{array}{l}\text { Primer: acrylic ether phosphonic acid, } \\
\text { bisacrylamide, water, CQ, stabilizers Primer: } 1.7 \\
\text { Light cure Dry } \\
\text { Bonding: Bis-GMA, GDMA, HEMA, fumed silica, } \\
\text { CQ, tertiary amine, stabilizers }\end{array}$ \\
\hline $\begin{array}{l}\text { Prime\& Bond NT } \\
\text { (Dentsply/DeTrey) }\end{array}$ & $\begin{array}{l}\text { Bond. } \\
\text { Agent }\end{array}$ & NT & $\begin{array}{l}\text { Adhesive: PENTA, TEGDMA, Bis-GMA, cetylamine } \\
\text { hydrofluoride, acetone, nanofiller (amorphous silicon } \\
\text { dioxide } 8 \mathrm{~nm} \text { ), resin R5-62-1, T-resin, D-resin, CQ }\end{array}$ \\
\hline $\begin{array}{l}\text { XENO } \\
\text { V(Dentsply/DeTrey) }\end{array}$ & $\begin{array}{l}\text { Bond. } \\
\text { Agent }\end{array}$ & $X V$ & $\begin{array}{l}\text { Bifunctional acrylate, acidic acrylate, functionalized } \\
\text { phosphoric ester, acrylic acid, water, t-butanol, CQ, } \\
\text { stabilizer }\end{array}$ \\
\hline $\begin{array}{l}\text { XP Bond } \\
\text { (Dentsply/DeTrey) }\end{array}$ & $\begin{array}{l}\text { Bond. } \\
\text { Agent }\end{array}$ & $X P$ & $\begin{array}{l}\text { TCB resin, PENTA, UDMA, TEGDMA, HEMA, } \\
\text { butylated benzenediol, ethyl-4- } \\
\text { dimethylaminobenzoate, CQ, amorphous silica, t- } \\
\text { butanol }\end{array}$ \\
\hline $\begin{array}{l}\text { Pattern Resin } \\
\text { (GC, Europe) }\end{array}$ & Die Material & PR & Polymethyl methacrylate \\
\hline $\begin{array}{l}\text { Flexacryl (Lang } \\
\text { Dental }\end{array}$ & $\begin{array}{l}\text { Hard } \\
\text { denture } \\
\text { reliner }\end{array}$ & FLEX & Ethyl methacrylate \\
\hline $\begin{array}{l}\text { Refit (Laybond Co } \\
\text { Inc., UK }\end{array}$ & $\begin{array}{l}\text { Hard } \\
\text { denture } \\
\text { reliner }\end{array}$ & REFIT & Methyl methacrylate \\
\hline Jet (Lang Dental) & $\begin{array}{l}\text { Provisional } \\
\text { crown and } \\
\text { bridge } \\
\text { material }\end{array}$ & JET & Methyl methacrylate \\
\hline
\end{tabular}

\section{RESULTS}

Disinfectants

In Figures 2 (a), (b) and (c) statistical values (medians, min, max, 25th and 75th percentiles) of the TVOCs concentrations from disinfectant sprays and wipes measured right above the source, $50 \mathrm{~cm}$ and $100 \mathrm{~cm}$ are presented in the form of Box-and-Whiskers plots. Significant differences are 
observed between TVOCs emitted from sprays and tissues, the former being in general substantially higher than the latter (average TVOCs conc. from sprays $8327 \mathrm{ppb}$, while the respective value for tissues is $496 \mathrm{ppb}$ ). TVOCs emitted from sprays vary significantly: the highest values correspond to BL.s (median=7.678 ppb; 25th percentile $=2.165 \mathrm{ppb}$; 75th percentile $=55.180 \mathrm{ppb}$ ) while values close to background values are observed for S.s (median=97 ppb; 25th percentile=95 ppb; 75th percentile $=99 \mathrm{ppb})$. BL.s concentrations are in general extremely high. These results are in agreement with the BL.s concentrations measured in a different dental setting, under different background concentrations (Helmis et al., 2008). SD.s and DM.s show similar TVOCs concentrations (medians $1.922 \mathrm{ppb}$ and $1.705 \mathrm{ppb}$, respectively) and rather high concentrations are presented for D.s (median= $429 \mathrm{ppb}$; 75th percentile= $2.862 \mathrm{ppb}$ ). TVOCs resulting from tissues vary between very low, background values (S.w) and moderate values (BL.w). More specifically: very low background values are observed for S.w (median $=9 \mathrm{ppb}$; 75th percentile $=12 \mathrm{ppb}$ ), while for BL.w and HT.w the corresponding values are substantially higher (medians: $821 \mathrm{ppb}$ and $431 \mathrm{ppb}$; 75th percentiles $989 \mathrm{ppb}$ and $570 \mathrm{ppb}$ respectively).

At $50 \mathrm{~cm}$ and $100 \mathrm{~cm}$ distance from the source, TVOCs concentrations are strongly reduced comparing to the above-the-source values for several disinfectants (Figure 2 (b) and (c)). The reduction is more prominent for BL.s (percentage reduction equal with $90 \%$ ), while it is small for S.S and S.w apparently due to the very low concentrations. Mean values are still quite high at 50 and $100 \mathrm{~cm}$ for the majority of the disinfectant agents. Concentrations higher than (or equal to) $1000 \mathrm{ppb}$ were observed at $50 \mathrm{~cm}$ and $100 \mathrm{~cm}$ for SD.s, DM.s BL.s. Moderate concentrations are observed for BL.w and HT.w at $100 \mathrm{~cm}$ (657 ppb and $355 \mathrm{ppb})$.

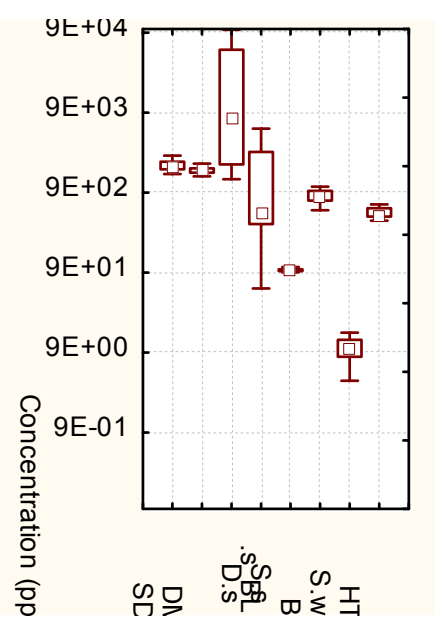

(a)

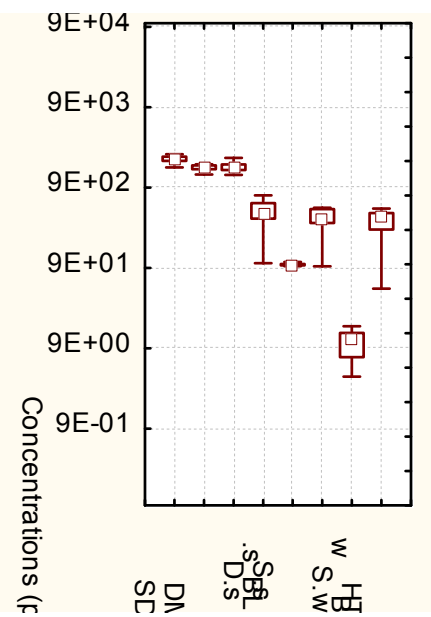

(b)

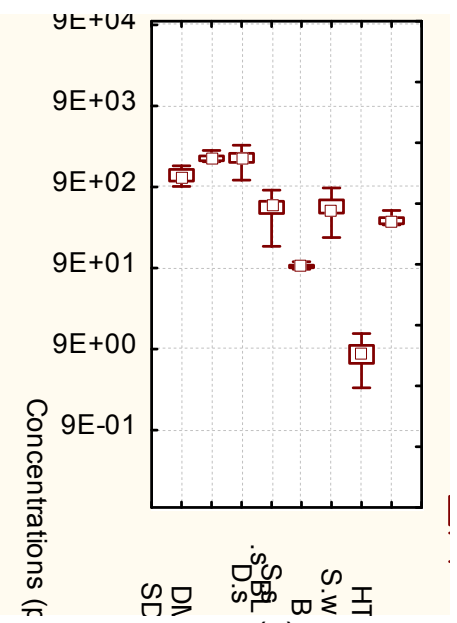

(c)

Figure 2. Box-and-Whiskers plots of the TVOC concentrations (10-s averages) from disinfectant sprays right above the source (a) $50 \mathrm{~cm}$ (b) and $100 \mathrm{~cm}$ (c) away from the source. Vertical axis is in logarithmic scale

\section{Bonding agents}

Box and Whiskers plots for TVOCs emitted from bonding agents which were spread are presented in Figure 3 (a), (b) and (c). The highest emitted TVOCs are observed for OPT(aio) and NT and the lowest emissions correspond to ADH. Even though away from the source TVOCs concentrations drop significantly to near background values, high values (near $500 \mathrm{ppb}$ ) are detected in certain cases (e.g. 6.NT at $100 \mathrm{~cm}$ ).

\section{Acrylic substances}

Box and Whiskers plots for TVOCs emitted from acrylic substances are presented in Figure 4 (a), (b) and (c). High TVOCs concentrations are observed for all acrylic substances (e.g. mean value right above the source was equal to 32.720 ). It is of interest to note that even the $10^{\text {th }}$ percentile values are quite high $(4.056,1.030$ and $1.020 \mathrm{ppb}$ for Flex, Jet and PR respectively), indicating that the extremely high TVOCs levels are representative of the mean emission patterns. Even though that 
mean concentrations are significantly reduced away from the source, in certain cases they maintain high levels (e.g. PR mean concentration equals to $450 \mathrm{ppb}$ ).

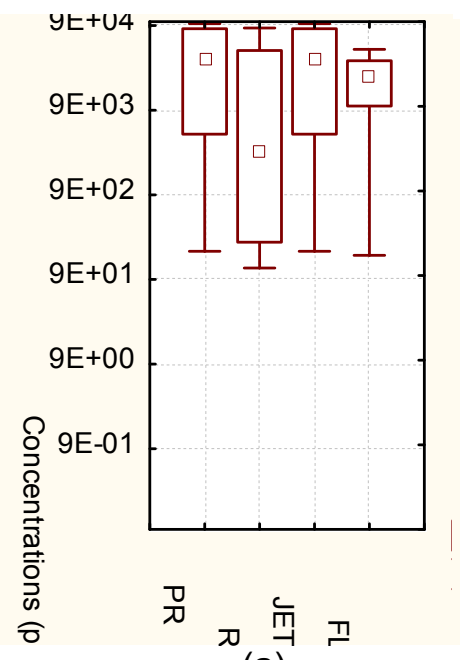

(a)

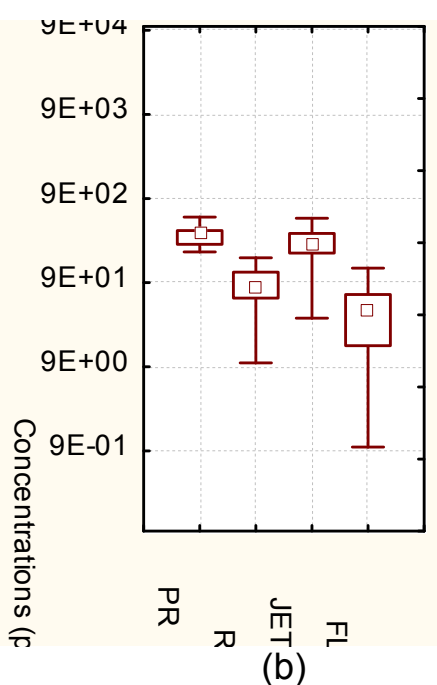

(b)

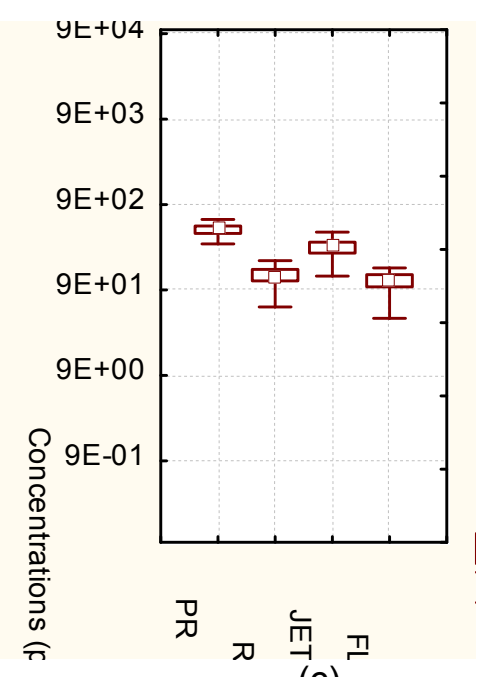

(c)

Figure 3. Results for bonding agents. a, b, c as in Figure 2 (Vertical axes are in logarithmic scale).

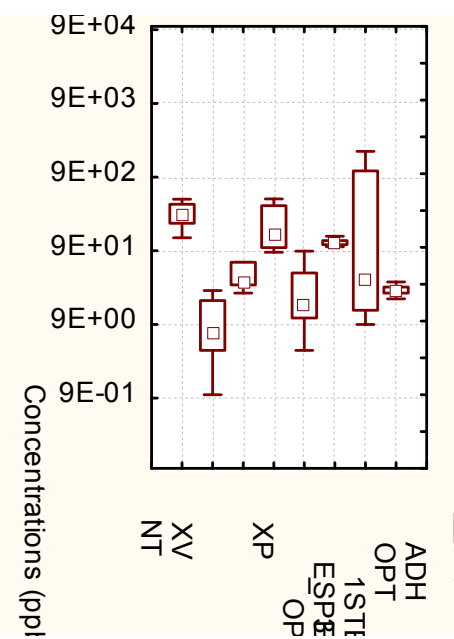

(a)

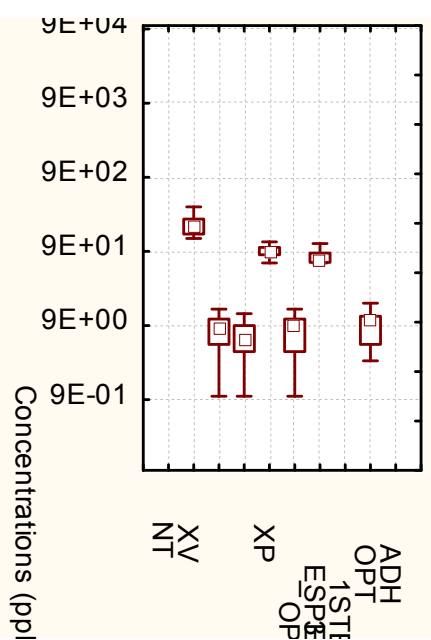

(b)

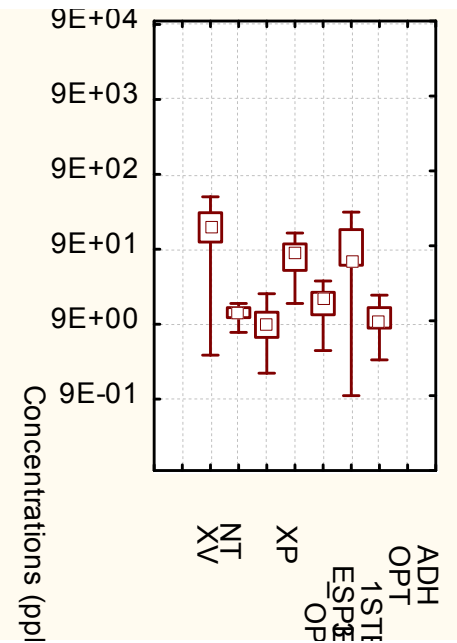

(c)

Figure 4. Results for acrylic substances .a, b, c as in Figure 1.

(Vertical axes are in logarithmic scale).

\section{Environmental factors}

Histograms of the wind speed, ventilation rates, and $\mathrm{CO}_{2}$ and water vapor concentrations right above the source (i.e. dental materials) are presented in Figure $5 . \mathrm{CO}_{2}$ production rate is more or less constant (i.e. the number of people within the room is almost constant). It would then be expected that $\mathrm{CO}_{2}$ and wind speed histograms would be similar, since they are controlled by the same factor, i.e. the ventilation rate. From Figure 5 it can be seen that $\mathrm{CO}_{2}$, wind speed and ventilation histograms are indeed similar. It is interesting to note though that water vapor histogram present significant differences, indicating that yet another process is acting, which is apparently the evaporation of the water contained in the dental materials. 


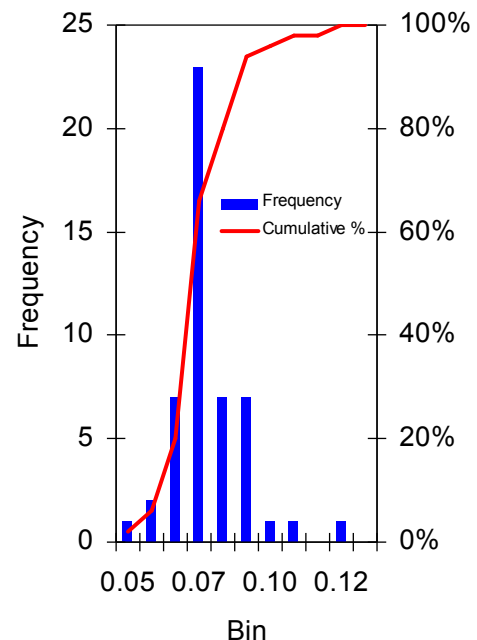

(a)

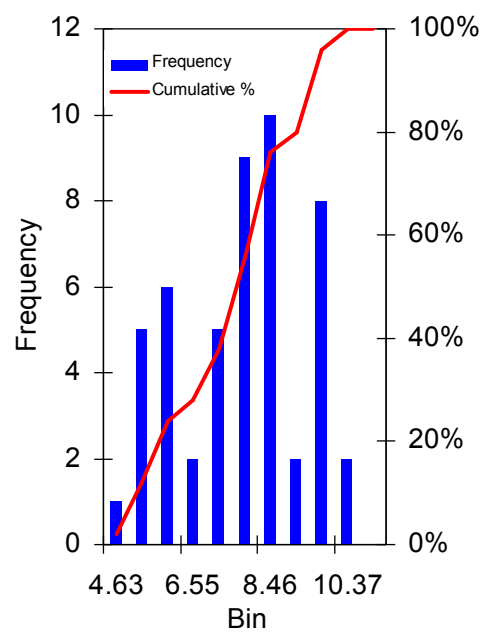

(c)

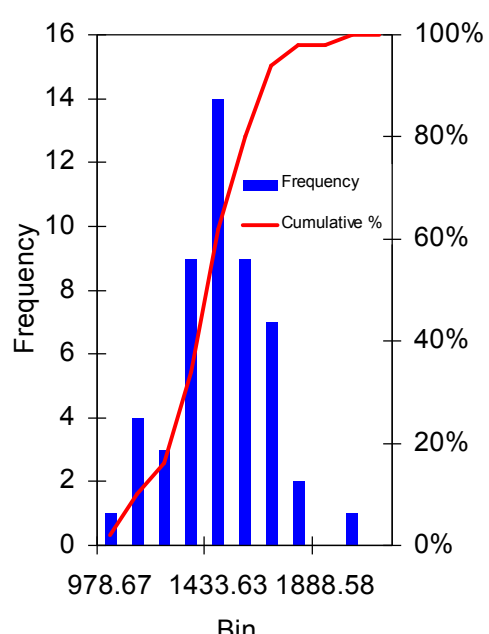

(b)

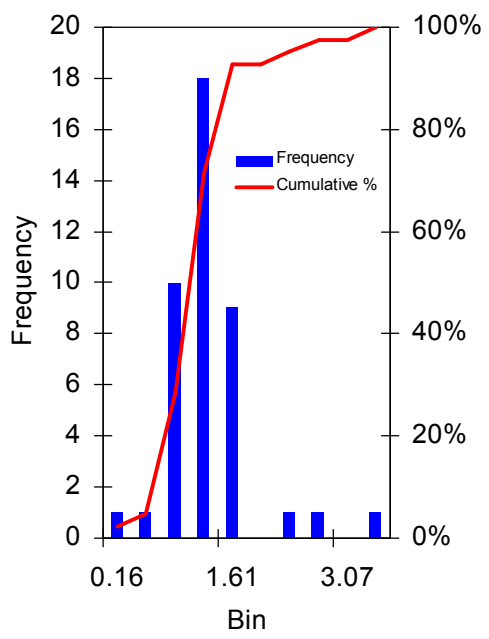

(d)

Figure 5. Histograms of wind speed (in $\left.\mathrm{m} \mathrm{s}^{-1}-\mathrm{a}\right) \mathrm{CO}_{2}\left(\mathrm{mg} \mathrm{m}^{-3}-\mathrm{b}\right)$ water vapour concentrations $(\mathrm{mmol} \mathrm{m}-\mathrm{c})$ and ventilation rates $\left(\mathrm{h}^{-1}-\mathrm{d}\right)$

In order to examine the influence of the environmental factors on the measured TVOCs concentrations, scatter plots of the horizontal wind speed, and relative humidity with the measured concentrations (Figure 6).

From Figure 6 it is evident that there is no direct dependence of the environmental factors on the measured concentrations, indicating the significance of the high emission patterns: apparently the possible dependence of TVOCs concentrations on environmental factors masked by the high emission patterns. An exception is observed for humidity, with a weak power-form correlation (0.36) indicating the connection between water evaporation and TVOCs concentrations. Thus for the high emissions from bonding agents, acrylic substances and disinfectants the ventilation rates commonly experienced in the indoor environment have little influence on the indoor TVOCs concentrations. 


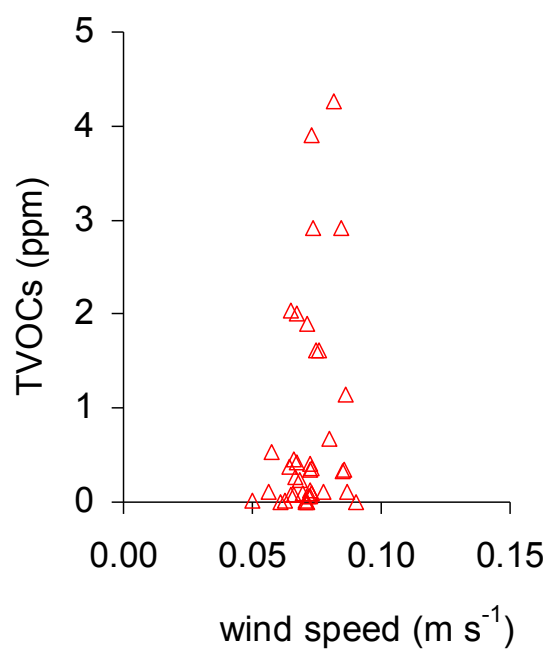

(a)

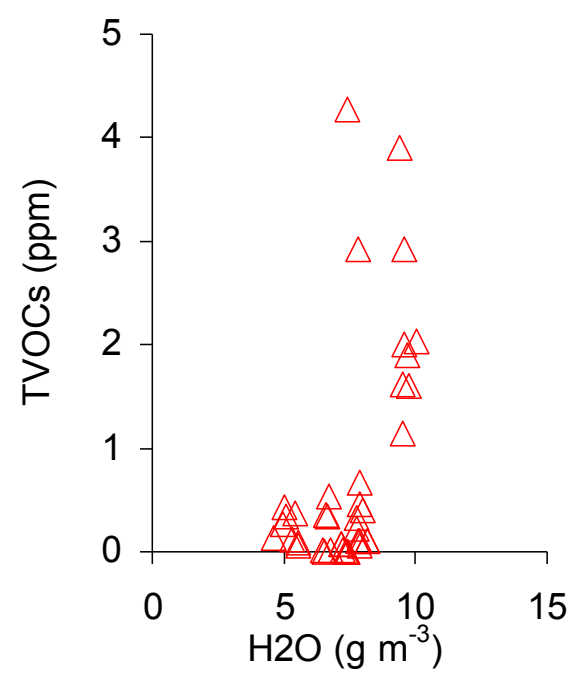

(c)

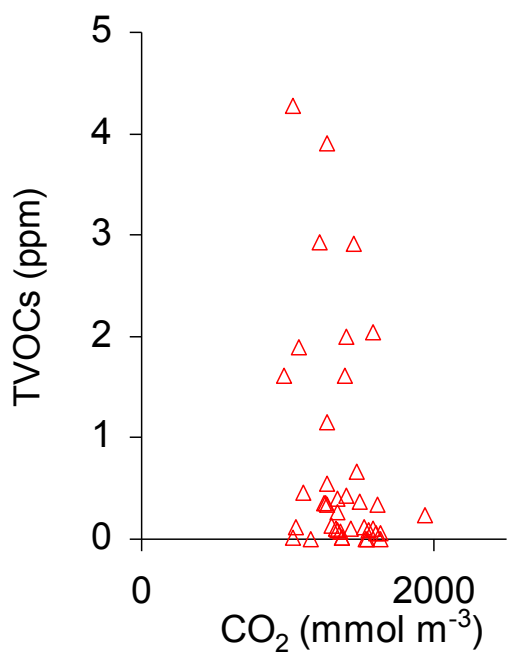

(b)

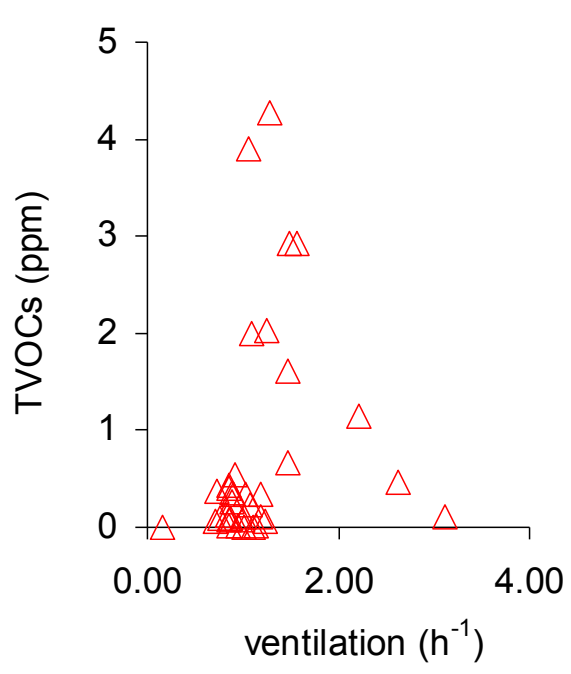

(d)

Figure 6. Scatter plot of the concentrations versus horizontal wind speed, humidity $\mathrm{CO}_{2}$ and ventilation rates

\section{Conclusions}

In this study, TVOCs emitted from commonly used dental substances in a controlled dental microenvironment were measured. TVOCs concentrations were monitored at three distances from the sources and environmental factors were assessed using a prototype experimental setup consisted of a sonic anemometer and a hygrometer right above the source. Ventilation rates were estimated via $\mathrm{CO}_{2}$ concentrations.

For disinfectants, above the source the concentrations ranged between $30.430 \mathrm{ppb}$ and $10 \mathrm{ppb}$ with an average value $5.393 \mathrm{ppb}$. High TVOCs concentrations were found to be emitted from three out of the four acrylic substances, with average values as high as $42.000 \mathrm{ppb}$. Concentrations were substantially reduced away from the source (average values below $500 \mathrm{ppb}$ for all substances). For bonding agents, it was found that the emitted TVOCS concentrations were significantly lower than the ones emitted from acrylic substances and disinfectants.

Influence of environmental factors such as ventilation rates, and indoor wind speed on the measured TVOCs concentrations is not traceable, indicating that for the emission patterns commonly 
experienced in dental offices the indoor air should be replaced with cleaner outdoor air by opening the windows as often as possible.

\section{ACKNOWLEDGEMENTS}

This work was supported by the Special Account for Research Grants of the University of Athens.

\section{REFERENCES}

1. Evans G., Cadogan D., Flueckiger A., Hennes C. and Kimber I. (2008) Chemical pollution , respiratory allergy and asthma: a perspective - Review, J Appl Toxicol, 28, 1-5

2. Godwin C.C., Batterman S.A., Sahni S.P. and Penge C.Y. (2003) Indoor environment quality in dental clinics:potential concerns from particulate matter, Am J Dent, 16(4), 260-266

3. Helmis C.G., Tzoutzas J., Flocas H.A., Halios C.H., Stathopoulou O.I., Assimakopoulos V.D., Panis V., Apostolatou M., Sgouros G. and Adam E.(2007) Indoor air quality in a dentistry clinic, Sci Total Environ, 377(2-3), 349-365.

4. Helmis C.G., Tzoutzas J., Flocas H.A., Halios C.H., Assimakopoulos V.D., Stathopoulou O.I., Panis V. and Apostolatou M. (2008), Emissions of total volatile organic compounds and indoor environment assessment in dental clinics in Athens, Greece, International Dental Journal, 58(5), 269-278.

5. Marquardt W., Seiss M., Hickel R. and Reichl F. (2009) Volatile Methacrylates in Dental Practices, $J$ Adhesive Dent, 11, 101-107.

6. Pechter E., Davis L., Tumpowsky., Flattery J., Harrison R., Reinisch F. (2005) Work-related asthma among health care workers: Surveillance data from California, Massachusetts, Michigan and New Jersey 1993-1997, Am J Indust Med, 47, 265-275.

7. Pappas G.P., Herbert R.J., Henderson W., Koenig J., Stover B. and Barnharty S. (2000) The respiratory effects of volatile organic compounds, Int J Occup Environ Health, 6(1), 1-8.

8. Wolkoff P. (1995) Volatile organic compounds-sources, measurements, emissions and the impact on indoor air quality, Indoor air, 5, 196-203. 